\title{
Impact of COVID-19 Pandemic on IAKN Tarutung Students
}

\author{
Limmarten Simatupang \\ Philippine Normal University, Manila, Philippines \\ E-mail address marten.simatupang@gmail.com
}

\begin{abstract}
This study aims to reveal the impact of the COVID-19 pandemic on IAKN Tarutung students. An online survey was conducted in August 2020 to collect the information using Google Form. A total of 182 students provided complete information regarding the survey. The study finds that the main problem faced by students is costs for buying internet data, poor internet quality, and students not able to understand the learning materials delivered through online learning.
\end{abstract}

Keywords: COVID-19, IAKN Tarutung, students

\section{INTRODUCTION}

Currently, our world is being hit by the COVID-19 pandemic. COVID-19 pandemic caused by a new type of virus called coronavirus. As of September 20, 2020; COVID-19 disease has infected 30,675,675 people worldwide, with 954,417 death cases (who.int). In Indonesia, the first COVID-19 positive case was detected on March 2, 2020. Since then, cases have increased, and the disease has spread to various provinces in Indonesia. According to data as of September 20, 2020, Indonesia has 244,676 positive cases, with 177,327 recovered cases and 9,553 death cases (detik.com).

COVID-19 pandemic has many impacts on human life. It began with limited human activity outside the home, which then affects other aspects, including health aspect, social aspect, economic aspect, and education aspect. In the education sector, this pandemic has educational institutions being closed. The closure of educational institutions due to the COVID-19 pandemic has had an unprecedented impact on education. During the lockdown, teachers are instructed to teach through an online learning platform (Abidah, Hidaayatullaah, Simamora, Fehabutar, \& Mutakinati, 2020).

For students, this situation forces them to study from home. Students also face problems in finance and health - for example, lack of resources to complete their studies or fear of becoming seriously ill. The transition to online learning affects academic performance, educational plans, current labor market participation, and expectations about future employment. (Aucejo, French, Araya, and Zafar, 2020). Students have faced various problems related to anxiety, depression, poor internet connectivity, and an unfavorable learning environment at home. Students face the various effects of this pandemic. This study aims to reveal the impact of the COVID-19 pandemic on IAKN Tarutung students. IAKN Tarutung is located in Tarutung, North Sumatera Province, Indonesia.

\section{LITERATURE REVIEW}

\section{II.1. Subjects}

This is an online survey-based study of the 182 students from several majors of IAKN Tarutung. 


\section{II.2. Data collection and procedure}

An online survey was conducted in August 2020 to collect the information. A structural questionnaire link using 'Google form' was sent to students' through WhatsApp and E-mail.

\section{II.3. Data analysis}

Descriptive statistics were used to explore participant's experiences related to learning methods, online platforms, and problems related to the study due to the COVID-19 pandemic. Data analyzed using IBM SPSS version 23 .

\section{RESULTS AND DISCUSSION}

\section{III.1. Respondents Characteristics}

Data were collected from 182 students of IAKN Tarutung who came from various undergraduate majors and batch. Most of the students were from the Christian Education major (49.5\%). It is consistent with the fact that most students of IAKN Tarutung come from Christian Religious Education major. According to batch, respondents come from 2015 batch (2.2\%), 2016 batch (23.6\%), 2017 batch (11.0\%), 2018 batch $(24.7 \%)$ and 2019 batch (38.5\%). Respondents consist of female as many 151 students $(83.0 \%)$ and male as many 31 students $(17.0 \%)$. Most of the respondents are aged 20-22 years old $(64.8 \%)$. The characteristics of the respondents can be seen in Table 1 below:

Table 1. Characteristics of Respondents

\begin{tabular}{|c|c|c|}
\hline Characteristics & Frequency & Percentage \\
\hline \multicolumn{3}{|l|}{ Major } \\
\hline Christian Education Management & 17 & 9.3 \\
\hline Cultural and Religious Tourism & 29 & 15.9 \\
\hline Pastoral Counseling & 2 & 1.1 \\
\hline Christian Education & 90 & 49.5 \\
\hline Early Childhood Christian Education & 6 & 3.3 \\
\hline Church Music Education & 11 & 6.0 \\
\hline Sociology of Religion & 21 & 11.5 \\
\hline Theology & 6 & 3.3 \\
\hline Total & 182 & 100.0 \\
\hline \multicolumn{3}{|l|}{ Batch } \\
\hline 2015 & 4 & 2.2 \\
\hline 2016 & 43 & 23.6 \\
\hline 2017 & 20 & 11.0 \\
\hline 2018 & 45 & 24.7 \\
\hline 2019 & 70 & 38.5 \\
\hline Total & 182 & 100.0 \\
\hline \multicolumn{3}{|l|}{ Sex } \\
\hline Female & 151 & 83.0 \\
\hline Male & 31 & 17.0 \\
\hline Total & 182 & 100.0 \\
\hline \multicolumn{3}{|l|}{ Age } \\
\hline $17-19$ & 38 & 20.9 \\
\hline
\end{tabular}




\begin{tabular}{lcc}
$20-22$ & 118 & 64.8 \\
$23-25$ & 25 & 13.7 \\
$26-28$ & 1 & 0.5 \\
Total & 182 & 100.0 \\
\hline
\end{tabular}

Table 2 displays the condition of respondents based on the area of origin and residence. Respondents consisted of 30 students (16.5\%) from an urban area and 152 students $(83.5 \%)$ from rural areas. Based on a residence, they live with their parents as 25 students, live in a boarding house as many 104 students, and live in the dormitory as many 53 students.

Table 2. Area of Origin and Residence of Respondents

\begin{tabular}{lcc}
\hline \multicolumn{1}{c}{ Characteristics } & Frequency & Percentage \\
\hline Area of Origin & & \\
Urban Area & 30 & 16.5 \\
Rural Area & 152 & 83.5 \\
Total & 182 & 100 \\
& & \\
Residence & & \\
Live with their parents & 25 & 13.7 \\
Boarding house & 104 & 57.1 \\
Dormitory & 53 & 29.1 \\
Total & 182 & 100.0 \\
\hline \hline
\end{tabular}

\section{III.2. Students Opinion Toward The Closure of School}

Since March, IAKN Tarutung was closed due to the COVID-19 pandemic. Since March, IAKN Tarutung has been closed due to the COVID-19 pandemic. This closure aims to prevent the spread of the virus. Because of this, students cannot study in the classroom. Respondents' opinion toward the closure of IAKN Tarutung consisted of 112 students (61.5\%) who agree, 34 students (18.7\%) disagree, and 36 students $(19.8 \%)$ stated don't know. Figure 1 display students opinion toward the closure of IAKN Tarutung:

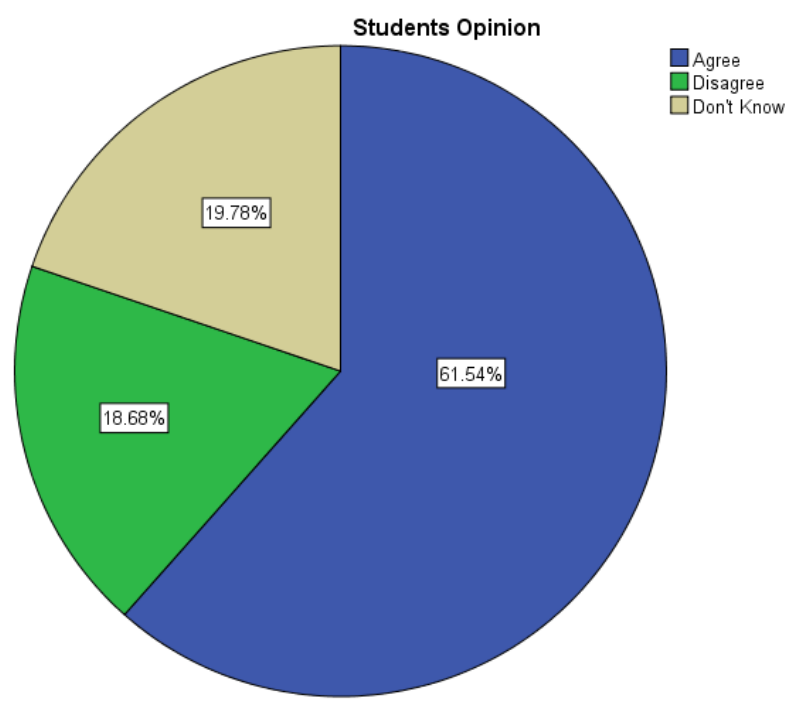

Figure 1. Students opinion toward the closure of IAKN Tarutung 


\section{III.3. Learning Methods During Distance Learning}

The closure of the campus resulted in IAKN Tarutung must carrying out distance learning. The learning method during distance learning was the assignment method used by 12 respondents $(6.6 \%)$. As many as 159 respondents $(87.4 \%)$ often took part in learning using the WhatsApp application. Meanwhile, 11 respondents $(6.0 \%)$ more often attended online video learning. The learning method most frequently followed by respondents can be seen in Table 3 below:

Table 3. Learning Methods During Distance Learning

\begin{tabular}{cccc}
\hline \multicolumn{2}{c}{ Variable } & Frequency & Percentage \\
\hline $\begin{array}{c}\text { Learning Methods During } \\
\text { Learning }\end{array}$ & Distance & & \\
Assignment Method & & 12 & 6.6 \\
Learning using & Whatsapp & 159 & 87.4 \\
application & & 11 & 6.0 \\
Online Video Learning & & 182 & 100.0 \\
Total &
\end{tabular}

\section{III.4. Platforms for Distance Learning and Material Sharing}

The platforms used in the online classroom is Zoom, which was chosen by respondents 118 times (this means the proportion is $65 \%$ ), Google Classroom was chosen 77 times (42\%), WhatsApp was chosen 58 times (32\%), Youtube Live was chosen 16 times (9\%), and Google Meet was chosen 15 times (8\%). It means that the platforms most frequently used by respondents for the online classroom is Zoom, then respectively Google Classroom, WhatsApp, Youtube Live, and Google Meet. Meanwhile, the platforms for material sharing are Whatsapp, email, and Facebook Messenger. The platforms most used by respondents can be seen in Table 4 below:

Table 4. Platforms for Distance Learning and Material Sharing

\begin{tabular}{lcc}
\hline \multicolumn{1}{c}{ Variable } & Frequency & Proportion \\
\hline Online Classroom Application & & \\
Zoom & 118 & 64.8 \\
Google Classroom & 77 & 42.3 \\
Whatsapp & 58 & 31.9 \\
Youtube Live & 16 & 8.8 \\
Google Meet & 15 & 8.2 \\
Sharing File Application & & \\
Whatsapp & 160 & 87.9 \\
Email & 143 & 78.6 \\
Facebook Messenger & 3 & 1.6 \\
\hline
\end{tabular}

\section{III.5. Devices for Distance Learning}

Based on the device, the majority of respondents used smartphones when attending distance learning, namely 164 students (90.1\%). At the same time, 15 students use laptops $(8.2 \%)$, and four students $(1.7 \%)$ use both. According to ownership, 175 students (96.2\%) stated that the device was their own. Meanwhile, 
seven students (3.8\%) stated that the device was not their own. Devices used by the respondent and its ownership displayed in Table 5 below:

Table 5. Devices for Distance Learning and Its Ownership

\begin{tabular}{lcc}
\hline \multicolumn{1}{c}{ Variable } & Frequency & Percentage \\
\hline Device & & \\
Smartphone & 164 & 90.1 \\
Laptop & 15 & 8.2 \\
Smartphone and Laptop & 4 & 1.7 \\
Total & 182 & 100 \\
& & \\
Ownership & 175 & 96.2 \\
His/Her Own & 7 & 3.8 \\
Not His/Her Own & 182 & 100 \\
Total & & \\
\hline
\end{tabular}

\section{III.6. Understanding Learning Materials}

Most of the respondents stated that they did not understand the learning materials presented online by their lecturer. Only 52 students $(28.6 \%)$ stated that they understood their learning materials, while 130 students $(71.4 \%)$ stated that they did not understand it. The condition of respondents related to understanding learning materials can be seen in Table 5 below:

Table 5. Understanding Learning Materials

\begin{tabular}{ccc}
\hline Variable & Frequency & Percentage \\
\hline Do you understand the learning materials presented online by your lecturer? \\
Yes & 52 & 28.6 \\
No & 130 & 71.4 \\
Total & 182 & 100 \\
\hline \hline
\end{tabular}

\section{III.7. Problems Faced by Students During Distance Learning}

There are several problems faced by students while carrying out distance learning. The problem most often faced is the costs of buying internet data. Then the problems related to internet quality. Most of the IAKN Tarutung students come from rural areas, while rural areas have poor internet quality. Students also find it difficult to understand the learning material during distance learning. Table 6 display problems faced by students:

Table 6. Problems faced by students during distance learning

\begin{tabular}{lcc}
\hline Variable & Frequency & Proportion \\
\hline $\begin{array}{c}\text { Problems faced by students } \\
\text { Costs for buying internet data }\end{array}$ & 120 & 65.9 \\
$\begin{array}{l}\text { Poor internet quality } \\
\text { Not able to understand the learning } \\
\text { materials delivered through online learning } \\
\begin{array}{c}\text { The living environment is not } \\
\text { conducive to learning }\end{array}\end{array}$ & 114 & 62.6 \\
\end{tabular}




$\begin{array}{cccccc}\text { Do not have a device (laptop, } & 7 & 3.8 \\ \text { smartphone) }\end{array}$

\section{III.8. Impact of COVID-19 Pandemic on Personal and Economic Condition}

COVID-19 pandemic affects students' personal life. A total of 157 students $(86.3 \%)$ stated that they felt stressed due to this outbreak. In addition, the economic condition of students is also disrupted. A total of 173 students (95.1\%) admitted that their family's economy was affected by the covid-19 outbreak. Table 7 display the impact of the COVID-19 pandemic on personal and economic condition:

Table 7. Impact of COVID-19 pandemic on the personal and economic condition

\begin{tabular}{lcc}
\hline Variable & Frequency & Percentage \\
\hline The personal and economic condition & & \\
Do you feel stressed due to the COVID-19 pandemic? & 157 & 86.3 \\
Yes & 25 & 13.7 \\
No & & \\
& & \\
Do your family's economy affected by the COVID-19 pandemic? & 95.1 \\
Yes & 173 & 4.9 \\
No & 9 & \\
\hline \hline
\end{tabular}

\section{III.9. Discussion}

COVID-19 pandemic has had a sudden impact on the education aspect. Changing the learning method in the classroom to distance learning has several effects. Respondents in this study admitted that they did not understand the learning material presented online. One way to overcome this problem is by conducting training for lecturers on how to implement distance learning properly.

Then the problem faced by students is about the internet, both quality and cost. Internet quality in rural areas is still poor. The government should be able to encourage internet providers to improve the quality of internet in rural areas. Internet providers should set prices according to the ability of the community.

Internet facilities are an important component of distance learning. In addition, the availability of devices such as laptops, computers, and smartphones is very important. Wan (2020) states there is a problem that children have to share devices, and they cannot fully take advantage of online lessons due to slow internet connection or lack of devices.

In addition, Aboagye, Yawson, and Appiah (2020) stated that students were not ready to experience online learning in this pandemic era. To help solve accessibility issues, internet operators must ensure strong internet connectivity and also reduce internet package costs.

COVID-19 pandemic has also caused students to experience stress. IAKN Tarutung can help students who are experiencing stress through counseling activities. Pastoral Counseling major of IAKN Tarutung can carry out counseling to help students who feel stressed.

\section{CONCLUSION}

IAKN Tarutung students are feeling the impact of the COVID-19 pandemic, namely on the learning sector, personal life, and economic conditions. The main problem faced is costs for buying internet data, 
poor internet quality, and they not able to understand the learning materials delivered through online learning.

\section{REFERENCES}

Aboagye, E., Yawson, J.A., Appiah, K.N. (2020). Covid-19 and e-learning the challenges of students in tertiary institutions in Ghana. Social Education Research, 1(1), 109-115.

Abidah, A., Hidaayatullaah, H.N., Simamora, R.M., Fehabutar, D., Mutakinati, L. (2020). The impact of covid-19 on Indonesian education and its relation to the philosophy of "merdeka belajar." Studies in Philosophy of Science and Education (SiPoSE). 1(1), 38-49.

E.M. Aucejo, J. French, M.P.U. Araya, et al. (2020). The impact of covid-19 on student experiences and expectations: evidence from a survey. Journal of Public Economics. PII: S0047-2727(20)301353.

Kapasiaa, N., Paulb, P., Royc, A., Sahac, J., Zaveric, A., Mallickc, R., Barmanc, B., Dasc, P., Chouhanc, P. (2020). Impact of lockdown on the learning status of undergraduate and postgraduate students during the covid-19 pandemic in West Bengal, India. Children and Youth Services Review, 116 (2020).

Wan, Y.S. (2020). Education during covid-19. Institute for Democracy and Economic Affairs. 